\title{
音響伝達特性の変化を考慮した評価点移動時の能動音響制御
}

\author{
横田 和哉*1, 木庭 洋介*22, 石川 諭*2, 雉本 信哉*3

\section{Active noise control for a moving evaluation point considering the change of acoustic transfer function} \\ Kazuya YOKOTA*1 $^{*}$, Yosuke KOBA ${ }^{* 2}$, Satoshi ISHIKAWA ${ }^{* 2}$ and Shinya KIJIMOTO ${ }^{* 3}$ \\ ${ }^{* 1}$ Department of Mechanical Engineering, Graduate School of Engineering, Kyushu University \\ 744 Motooka, Nishi-ku, Fukuoka 819-0395, Japan \\ ${ }_{2,2}^{*}$ Department of Mechanical Engineering, Faculty of Engineering, Kyushu University \\ 744 Motooka, Nishi-ku, Fukuoka 819-0395, Japan
}

Received: 2 October 2017; Revised: 1 January 2018; Accepted: 5 February 2018

\begin{abstract}
Because of using interference of sound wave, it is difficult to control in whole three-dimensional acoustic field by Active Noise Control (ANC). Instead, around-head-control is investigated in this paper. In this system, two error microphones are set near ears, and noise is reduced around evaluation points locally. This system requires fast adaptation speed of controller following movement of head, and a problem still remains that the control effect during movement becomes worse. Against this problem, we propose Modified Reference signal Method (MRM). This method improves adaptation speed during movement, by modification of filtering of input signal in Filtered- $x$. The secondary path model that controller requires is interpolated by the method Ohno et al. proposed. There is modeling error of secondary path caused by interpolation and measuring error of it, and this modeling error causes divergence of controller. In this paper, suppression method of divergence is also investigated. Suppression of divergence is executed by addition of penalty term to evaluation value, and it is equivalent to ridge regression mathematically. Proposed method requires a large number of matrix calculations, therefore reducing method of computational complexity according to acoustic characteristics is also investigated in this paper. The validity of the proposed method is shown by numerical simulation and experiment.
\end{abstract}

Keywords : Active noise conrol, Adaptive control, Digital control, Filtered- $x$ algorithm, Reast mean square (RLS) algorithm, Moving evaluation point, Ridge regression

\section{1. は じめに}

騒音を低減する手法の 1 つとして，騒音に対して別の音源から出力された制御音を干渉させて制御を行う能動 音響制御（Active Noise Control, ANC）がある. ANC を用いて広い範囲を制御することは簡易な機器構成では困難 であり，通常 1 つの制御音源によって制御される領域は小さい範囲に限定される。そこで，空間全体を制御する 代わりに，制御対象者の耳元に誤差マイクを設置してこれを評価点とし，評価点近傍を局所的に制御する手法が ある（鈴木他，2004）。空間全体を制御する必要が無いため, この手法では比較的簡易な機器構成で制御対象者は 騒音低減効果を得られる。しかし，この制御手法を用いる場合，制御対象者の頭部の移動に追従して静肃な領域 も移動するよう，制御系には高速・高精度な追従性能が求められる.

ANC に一般的に用いられる LMS（Least Mean Square）アルゴリズムは勾配法に基づいた手法であり，収束まで に一定の時間を要する，評価点移動時は，音響伝達経路の変化に追従して制御系が収束するために必要な時間が 確保できないために制御効果が大幅に悪化する問題がある。この問題に対して大野らは 2 次経路特性を補間しス

No.17-00446 [DOI:10.1299/transjsme.17-00446], J-STAGE Advance Publication date : 15 February, 2018

${ }^{*_{1}}$ 正員, 九州大学大学院 工学府 (T819-0395 福岡県福岡市西区元岡 744)

*2 正員, 九州大学大学院 工学研究院

*3 正員, フェロー, 九州大学大学院 工学研究院

E-mail of corresponding author: k.yokota@sky.mech.kyushu-u.ac.jp 
テップサイズベクトルを適用した Normalized LMS アルゴリズムで制御を行う方法（IP-NLMS-SV）を提案してい る（大野他， 2012）。このアルゴリズムは Filtered- $x$ 法で必要となる 2 次経路特性モデルを事前に数点同定してお き, 評価点移動時は事前測定点から補間を行い制御を行う。また，それに加えて適応フィルタの更新幅をフィル タ係数ごとに調整するステップサイズベクトルを用いることで，さらなる制御効果の向上を図る手法である． 2 次経路特性モデルを制御時に適応的に同定する必要がないこと, 及びステップサイズベクトルによる収束速度の 向上により, 評価点移動時の制御効果が LMS アルゴリズムと比較して向上することが確認されている. しかし, 依然として移動時には制御効果の劣化が見られ，移動時のさらなる制御効果向上は課題である.

本論文では最小二乗法を基本とし，Filtered- $x$ 法における参照信号の 2 次経路特性モデルによるフィルタリング 方法を修正することで評価点移動時の制御効果を向上させる参照信号修正法（Modified Reference signal Method， MRM）を提案する. Filtered- $x$ 法において必要となる 2 次経路特性モデルは大野らの提案した補間法により算出 する. 2 次経路特性モデルには補間や測定によって生じるモデル化誤差が存在し, 制御系が不安定になる可能性 があるため，モデル化誤差への対処方法についても述べる. また，提案法はフィルタ更新毎の計算量が $O\left(L^{3}\right)$ と

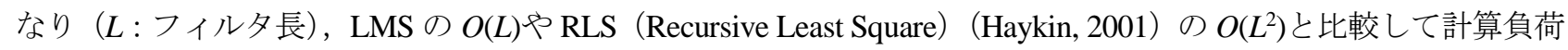
が高いため, 計算量を削減し, 少ない演算量で高い制御効果を得る方法についても述べる. 提案法の有効性は数 值シミュレーション及び実験で確認する。

\section{2. 提案法の原理}

本章では提案法の原理について説明する．移動に適した評価量の設定方法，仮想フィルタードリファレンス信 号の定義, 及び提案法のフィルタ算出方法について述べる. その中で, 2 次経路特性のモデル化誤差への対処方 法と, 計算量削減方法についても述べる.

\section{$2 \cdot 1$ 制御系の概要}

本論文で提案する手法は Filtered- $x$ 法を基本とする，提案法のブロック線図を図 1 に示す．図において $W$ は騒 音源から誤差マイクまでの音響伝達特性（1 次経路特性）， $\boldsymbol{W}_{\text {ref }}$ は騒音源から参照マイクまでの音響伝達特性， $\boldsymbol{G}$

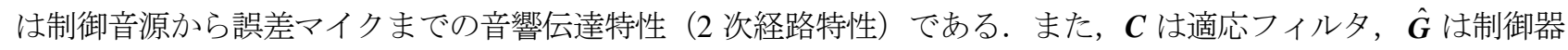
内部の 2 次経路特性モデル（2 次経路特性を模した FIR フィルタ）である. また， $x$ は騒音， $d$ は誤差マイクで取 得した騷音 (所望信号) , $r$ は参照マイクで取得した騒音 (参照信号),$u$ は制御音源（ 2 次音源）から出力される 音， $y$ は制御音源から誤差マイクに伝わる音 (制御音) , $e$ は $d$ と y が干渉し合った結果誤差マイクで観測される 音 (誤差信号), $\hat{d}$ は制御器内部で仮想的に算出される所望信号 (仮想所望信号), $\hat{f}$ は後述する修正されたフィ ルタードリファレンス信号（仮想フィルタードリファレンス信号）である. 図中に点線で囲った部分のうち，上 半分が実際の音場に相当し, 下半分が制御器内部に相当する.

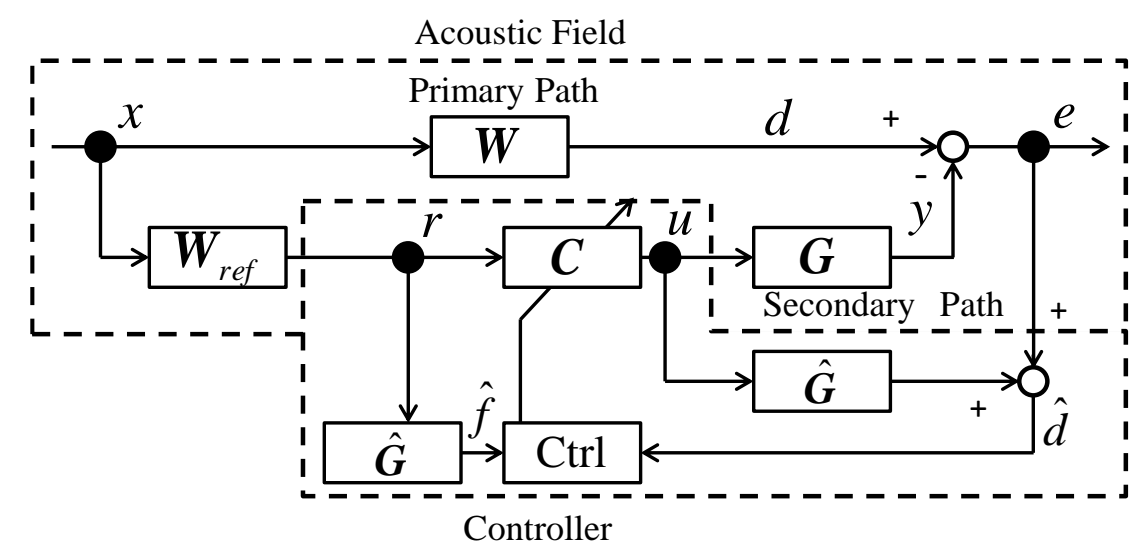

Fig. 1 Block diagram of proposed method.

Controller calculates adaptive filter $\boldsymbol{C}$ from information of $\hat{f}, \hat{d}$, and $\hat{\boldsymbol{G}}$. 
ブロック線図より，適応フィルタ $\boldsymbol{C}$ の最適な周波数特性 $\boldsymbol{C}_{\text {opt }}$ は

$$
\boldsymbol{C}_{\text {opt }}(\omega)=\frac{\boldsymbol{W}(\omega)}{\boldsymbol{W}_{r e f}(\omega) \boldsymbol{G}(\omega)}
$$

となることがわかる.

\section{2 - 2 評価量の設定及び適応フィルタの算出の基本的原理}

提案法における評価量の設定と，フィルタ算出方法の基本的原理について述べる. 制御器内部で仮想的な誤差 信号を考え，その 2 乗和を最小にする適応フィルタ $C(L \times 1$ 行列， $L$ : フィルタ長）を，最小二乗法を用いて求 める. ここでフィルタを更新する時刻を $k$, 変数としての時刻を $i$ とて , 添え字を用いてフィルタや信号の時刻 を表すこととする $(i \leq k)$.

提案法における仮想的な誤差信号 $\hat{e}$ は，評価点における仮想的な騒音 $\hat{d}$ と仮想的な制御音（ブロック線図上で 2 次経路特性モデル $\hat{\boldsymbol{G}}$ にフィルタリングされる $u$ ）を干渉させることにより算出される． $\hat{e}$ はブロック線図より 畳み込み演算で以下のように表される.

$$
\left.\begin{array}{rl}
\hat{e}_{i, k} & =\hat{d}_{i}-\hat{\boldsymbol{G}}_{k} * \boldsymbol{u}_{i} \\
& =\hat{d}_{i}-\hat{\boldsymbol{G}}_{k} * \boldsymbol{C}_{k} * \boldsymbol{r}_{i} \\
& =\hat{d}_{i}-\boldsymbol{C}_{k} * \hat{\boldsymbol{G}}_{k} * \boldsymbol{r}_{i} \\
& =\hat{d}_{i}-\boldsymbol{C}_{k} * \hat{\boldsymbol{f}}_{i, k}
\end{array}\right\}
$$

よって $\hat{e}_{i, k}$ はベクトル形式で次式により表される.

$$
\hat{e}_{i, k}=\hat{d}_{i}-\boldsymbol{C}_{k}^{T} \hat{\boldsymbol{f}}_{i, k}
$$

ただしここで

$$
\begin{aligned}
& \hat{\boldsymbol{f}}_{i, k}=\left[\hat{f}_{i, k}, \hat{f}_{i-1, k}, \cdots, \hat{f}_{i-L+1, k}\right]^{T} \\
& \hat{f}_{i, k}=\hat{\boldsymbol{G}}_{k}^{T} \boldsymbol{r}_{i} \\
& \hat{d}_{i}=e_{i}-\boldsymbol{G}_{i}^{T} \boldsymbol{u}_{i}
\end{aligned}
$$

であり， $\boldsymbol{u}, \hat{\boldsymbol{G}}, \boldsymbol{r}$ は $L \times 1$ 行列である. 式 (4) の $\hat{f}$ は本論文で提案する仮想フィルタードリファレンス信号で ある. 式（2）〜（5）において1番目の添え字は変数としての時刻を，2番目の添え字はフィルタ更新時刻を表 于.

$\hat{\boldsymbol{G}}$ を時変フィルタとして扱う場合に，従来一般的に用いられてきたフィルタードリファレンス信号は次式とな る（西村他，2006）.

$$
\begin{aligned}
\boldsymbol{f}_{i} & =\left[f_{i}, f_{i-1}, \cdots, f_{i-L+1}\right]^{T} \\
f_{i} & =\hat{\boldsymbol{G}}_{i}^{T} \boldsymbol{r}_{i}
\end{aligned}
$$

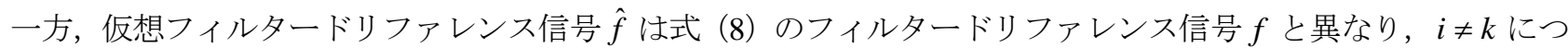
いても参照信号を更新時刻 $k$ での 2 次経路特性モデルでフィルタリングする。この変更が制御効果にもたらす影 響については後述する．従来のフィルタードリファレンス信号を用いた仮想的な誤差信号 $\hat{e}_{i}^{\prime}$ は

$$
\hat{e}_{i}^{\prime}=\hat{d}_{i}-C_{k}^{T} \boldsymbol{f}_{i}
$$

となり，これは一般的な RLS アルゴリズムにおける仮想的な誤差信号に相当する (Haykin, 2001). 
仮想フィルタードリファレンス信号を用いて, RLS アルゴリズムと同様に最小二乗法により $\boldsymbol{C}_{k}$ を求める. 評価 量 $J_{k}^{\prime}$ は $\hat{e}_{i}$ の二乗和として次式で定められる.

$$
J_{k}^{\prime}=\sum_{i=k-L s+1}^{k} \hat{e}_{i}^{2}
$$

ここで $L_{s}$ は系の変化に対応するために設けられる時間的な空の長さである. 提案法は現在から過去までの $L_{s}$ 点の サンプルのみ評価量として用いる．評価点移動時には音場の状態が刻一刻と変化するため, 評価量として用いる サンプルに時間的な制限を設けることで系の変化に追従した評価量を算出する.一般に $L_{s}$ が小さいほど評価点移 動時の制御効果が高くなるが，評価点停止時の制御効果は低下寸る.

式（10）に式（3）を代入すると次式が得られる.

$$
\boldsymbol{J}_{k}^{\prime}=\sum_{i=k-L s+1}^{k} \hat{d}_{i}^{2}-2 \boldsymbol{C}_{k}^{T}\left[\sum_{i=k-L s+1}^{k} \hat{d}_{i} \hat{\boldsymbol{f}}_{i, k}\right]+\boldsymbol{C}_{k}^{T}\left[\sum_{i=k-L s+1}^{k} \hat{\boldsymbol{f}}_{i, k} \hat{\boldsymbol{f}}_{i, k}^{T}\right] \boldsymbol{C}_{k}
$$

ここで自己相関行列 $\boldsymbol{R}(L \times L)$ と相互相関ベクトル $\boldsymbol{p}(L \times 1)$ を

$$
\left.\begin{array}{l}
\boldsymbol{R}_{k}=\sum_{i=k-L s+1}^{k} \hat{\boldsymbol{f}}_{i, k} \hat{\boldsymbol{f}}_{i, k}^{T} \\
\boldsymbol{p}_{k}=\sum_{i=k-L s+1}^{k} \hat{d}_{i} \hat{\boldsymbol{f}}_{i, k}
\end{array}\right\}
$$

とすると，式（11）は次式となる.

$$
\boldsymbol{J}_{k}^{\prime}=\sum_{i=k-L s+1}^{k} \hat{d}_{i}^{2}-2 \boldsymbol{p}_{k}^{T} \boldsymbol{C}_{k}+\boldsymbol{C}_{k}^{T} \boldsymbol{R}_{k} \boldsymbol{C}_{k}
$$

時刻 $k$ における適応フィルタの最適值 $\boldsymbol{C}_{o p t, k}$ は $J_{k}^{\prime}$ を極小にするフィルタ值として求められる． $J_{k}^{\prime}$ を極小にする $\boldsymbol{C}_{o p t, k}$ は最小二乗法として $\boldsymbol{J}_{k}^{\prime}$ の $\boldsymbol{C}_{k}$ による偏微分を 0 とおくことで

$$
\frac{\partial J_{k}^{\prime}}{\partial \boldsymbol{C}_{k}}=-2 \boldsymbol{p}_{k}+2 \boldsymbol{R}_{k} \boldsymbol{C}_{k}=0
$$

によって求められる.よって式（14）より， $\boldsymbol{C}_{o p t, k}$ の満たすべき条件は

$$
\boldsymbol{R}_{k} \boldsymbol{C}_{o p t, k}=\boldsymbol{p}_{k}
$$

となるので, 提案法における適応フィルタは, 次式で算出される.

$$
\boldsymbol{C}_{o p t, k}=\boldsymbol{R}_{k}^{-1} \boldsymbol{p}_{k}
$$

ここで評価点移動時における仮想フィルタードリファレンス信号の効果について説明する．この場合の前 提条件として, 前述したように適応フィルタ $\boldsymbol{C}$ の更新時刻を $k$ とする. この場合, フィルタを更新するため

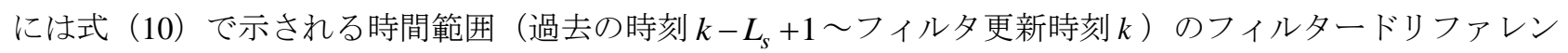
ス信号が必要となる.図 2 に示すように, 評価点移動時には 2 次経路特性が変化するため, $i \neq k$ の場合 $\hat{\boldsymbol{G}}_{i} \neq \hat{\boldsymbol{G}}_{k}$ となる. よって仮に, 式 (10) による評価量算出時に従来のフィルタードリファレンス信号 $f$ を用いると, フィルタ更新時刻 $k$ とは異なる, 過去の時刻での 2 次経路特性モデル $\hat{\boldsymbol{G}}_{i}$ に基づき評価量を算出するため, フ イルタ更新時刻に適した $C$ を算出寸ることができない. これに対して, 提案法の仮想フィルタードリファレ ンス信号 $\hat{f}$ では算出すべき $\boldsymbol{C}$ と参照信号のフィルタリングに用いる $\hat{\boldsymbol{G}}$ の時刻をフィルタ更新時刻である $k$ に 一致させている.この操作により, 式 (3) における $\boldsymbol{C}_{k}^{T} \hat{\boldsymbol{f}}_{i, k}$ は評価点が時刻 $k$ の位置で停止していた場合の仮 想的な制御音に相当することになり, 評価点の移動による影響を抑えた, より適切な評価量設定が行われる. 


\section{$2 \cdot 32$ 次経路のモデル化誤差への対応}

実際に提案法を ANC に適用寸るにあたっては, 2 次経路特性の近似值を 2 次経路特性モデル $\hat{\boldsymbol{G}}$ として制御系に 組み込む必要がある. 提案法では評価点移動時の 2 次経路特性モデルを，大野らの提案した補間法によって求め るため, 2 次経路の測定や補間に起因するモデル化誤差が生じる. モデル化誤差の一例として, 図 3 に補間され た 2 次経路特性と, 実測された 2 次経路特性との間の比較を示す.

モデル化誤差のため, 式（10）の評価量に基づき $\boldsymbol{C}_{o p t, k}$ を算出するとフィルタ係数が不適切に増大し，制御 系が発散するという問題が見られた。よって実際の適用に当たっては式 (10) を修正した評価量を使用する. 修正は $\boldsymbol{C}_{k}$ のフィルタ係数絶対值の増大に伴い $J_{k}^{\prime}$ が単調に増加するように $J_{k}^{\prime}$ にペナルティ項を追加すること によって行われる，修正された評価量 $J_{k}$ は次式となる.

$$
J_{k}=\sum_{i=k-L s+1}^{k} \hat{e}_{i}^{2}+\varepsilon \boldsymbol{C}_{k}^{T} \boldsymbol{C}_{k}
$$

ただし， $\varepsilon$ は正の定数である. 式（17）は数学的にはリッジ回帰と呼ばれる操作であり（落合，堀田，2008）, 最 小二乗法において解がサンプルの誤差に過剰に適応することを防ぐ効果がある. 最小二乗法を利用したアルゴリ ズムであるRLSアルゴリズムでは既にリッジ回帰を利用した制御系の安定化方法が提案されており(落合, 堀田, 2008), 式（17）における右辺第 2 項の追加はそれらと数学的に同等の操作である.

式（14）と同様に，評価量を最小とする $\boldsymbol{C}_{o p t, k}$ を $\partial J_{k} / \partial \boldsymbol{C}_{k}=0$ によって求めると，式（16）は以下のように修 正される.

$$
\boldsymbol{C}_{o p t, k}=\left(\boldsymbol{R}_{k}+\varepsilon \boldsymbol{I}\right)^{-1} \boldsymbol{p}_{k}
$$

ただしIは単位ベクトルである。

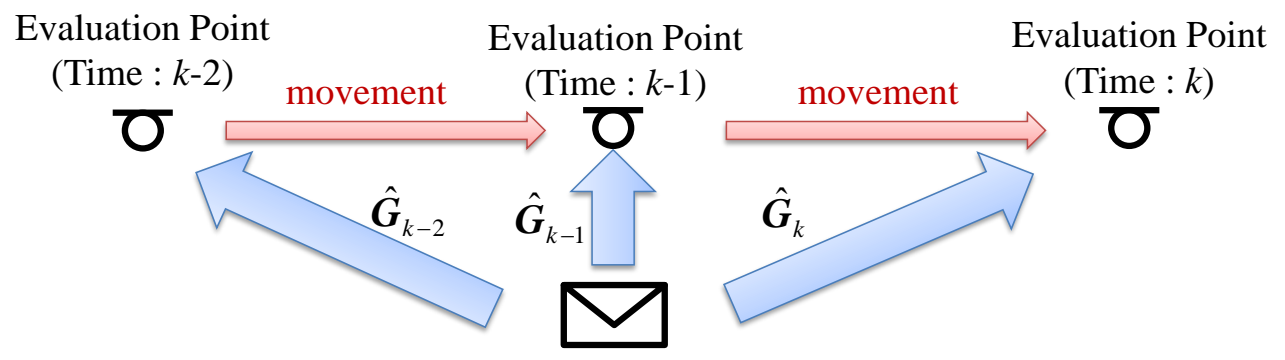

Fig. 2 Movement of evaluation point.

Secondary path changes due to movement of evaluation point.

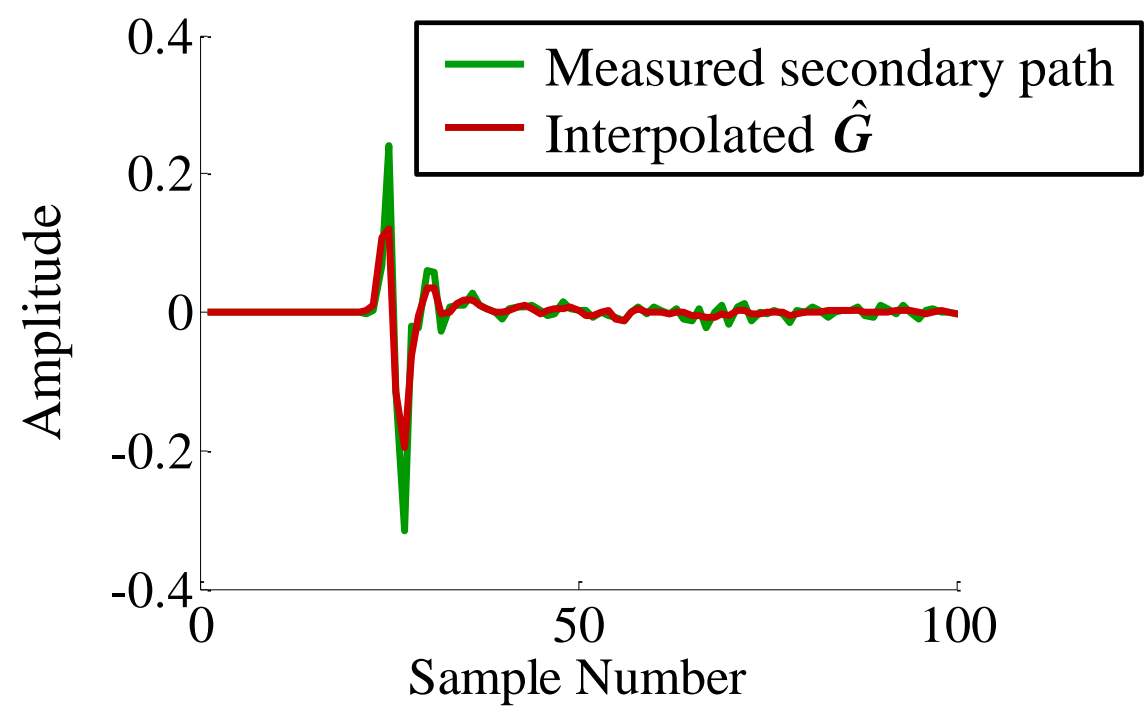

Fig. 3 Interpolated Secondary path. There is an interpolation error. 


\section{$2 \cdot 4$ 計算量の削減}

1 章で述べたように, 式 (18) を用いて $\boldsymbol{C}_{\text {opt }, k}$ を算出寸るためには $O\left(L^{3}\right)$ の計算量が必要であり，実際の適用に

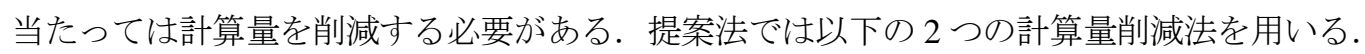

1 つ目の計算量削減法として, 更新対象とするフィルタ長を削減する. 図 4 に $\boldsymbol{C}_{k}$ のフィルタ概形を示す. $\boldsymbol{C}_{k}$ は式（1）で示される擬似的な音響伝達特性を実現するために，大きく分けて時間遅れ・主特性の 2 つ部分を持 つ. このうち, 適応フィルタに求められる主要な特性は一番初めのピーク付近の部分であり, 時間遅れ及び反射 音の部分には 0 に近い要素が多い. そこで, 図 5 の主要部以外のフィルタ係数を 0 として主要部分のみを更新対 象とする（図 5）と，更新が必要なフィルタ長を $L$ から $L_{w}$ に削減することができ，計算量を削減できる．評価点 の移動に伴い主要部の位置は変化するため, 更新対象とする主要部も時間軸方向（図 5 の横軸方向）に移動させ る. 主要部の検出はフィルタ係数絶対值の最大值を検出することによって行う.

2つ目の計算量削減法として, フィルタ更新頻度の削減を行う。これは式（18）による適応フィルタ算出を制

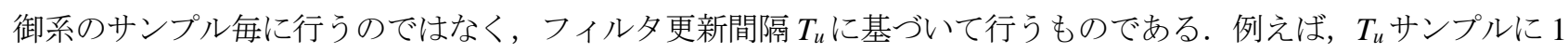
回フィルタを更新すれば，サンプル毎の計算量を最大で $1 / T_{u}$ に削減することができる. このようなフィルタ更新 頻度の削減が可能な理由は, 提案法においては式（18）に基づいて最適なフィルタを 1 回で求めるためである. LMS アルゴリズムは勾配を用いて反復計算によりフィルタを最適值に近づける方法のため, 例えばフィルタ更新 頻度を 100 回に 1 回とすると, 収束するまでの時間はサンプル毎に更新する場合と比較して 100 倍必要となり, LMS アルゴリズムの制御効果は大きく劣化する. それに対して, 提案法では式（18）によって最適なフィルタが 算出されるため, 最大でも 100 サンプルの遅れのみで最適な制御系の特性フィルタを算出することができる. よ って，LMS アルゴリズムと比較して収束性能を低下させずにフィルタ更新頻度を下げることが可能となる.

\section{3. 制 御 シ ミュレー シ ヨン}

本章では，提案法（Modified Reference signal Method, MRM）の有効性を数值シミュレーションで検証する.ま ず, 参照信号のフィルタリング方法の変更（仮想フィルタードリファレンス信号）の有効性を示すために, 従来 のフィルタードリファレンス信号を利用した制御との比較を行う。また， 2 次経路特性のモデル化誤差に対する 対策 $(2 \cdot 3$ 節）の有効性を検証するために， $\varepsilon$ を変化させて比較を行う。そして, 従来の代表的な ANCアルゴ リズムと制御効果・シミュレーション時間の比較を行い，提案法の有効性を確認する.

\section{$3 \cdot 1$ シミュレーション $1 ：$ 仮想フィルタードリファレンス信号の有効性検証}

本節では提案法における仮想フィルタードリファレンス信号の有効性を検証する. 無響室内で図 6 , 図 7 のよ うに機器を配置し，表 1 の条件で測定した音響特性を用いてシミュレーションを行う. 図 6 は騒音源の向きと制 御音源の向きが直交した直角配置であり, 図 7 は騒音源と制御音源が向かい合った対向配置である. 最小二乗法 において，従来のフィルタードリファレンス信号を使用した場合と仮想フィルタードリファレンス信号を使用し

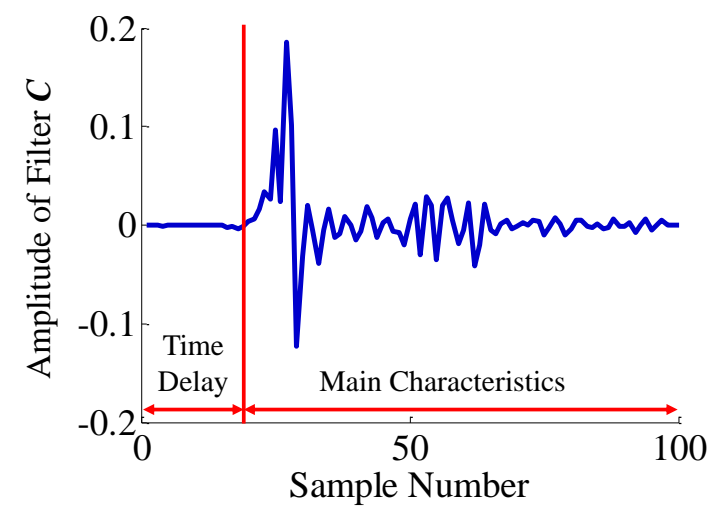

Fig. 4 Parts of filter $\boldsymbol{C}$.

Shape of $\boldsymbol{C}$ reflects acoustic characteristics of control field.

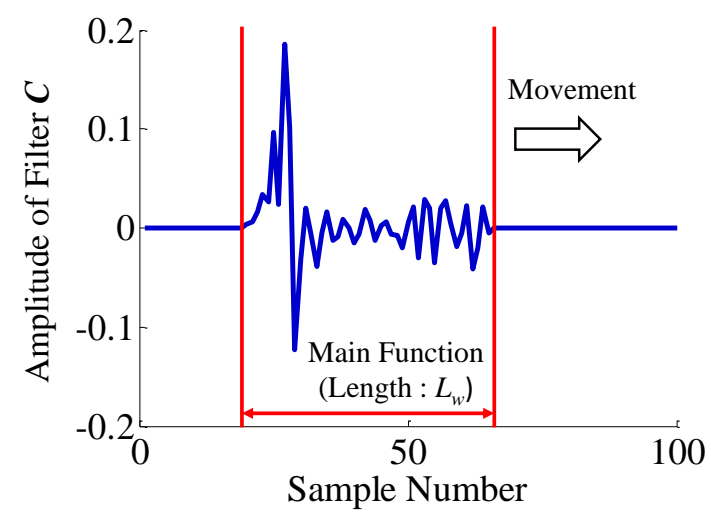

Fig. 5 Simplified filter $\boldsymbol{C}$.

$\boldsymbol{C}$ is simplified from Fig. 3 by defining main function. 


\section{た場合を比較する.}

シミュレーション条件を表 2 に示す.フィルタリング方法の変更による影響のみを調べるため, $2 \cdot 4$ 節で述べ たフィルタ係数の縮小による計算量の削減は行わず，制御に用いる 2 次経路特性モデル $\hat{\boldsymbol{G}}$ は測定した 2 次経路 特性と同一とする (補間は行わない). 評価点は図 6, 図 7 に示す点 $\mathrm{A} \rightarrow \mathrm{B}$ と移動するものとし, 移動速度は $0.2[\mathrm{~m} / \mathrm{s}]$ である.

シミュレーション結果を図 8 , 図 9 に示す. 図 8 は直角配置の結果を, 図 9 は対向配置の結果を示している. 図の横軸は時間，縦軸は推定誤差（Estimation Error, $E E$ ) である. EE は次式

$$
E E=10 \log _{10}\left(\frac{\sum_{i=k-511}^{k} e_{i}^{2}}{\sum_{i=k-511}^{k} d_{i}^{2}}\right)
$$

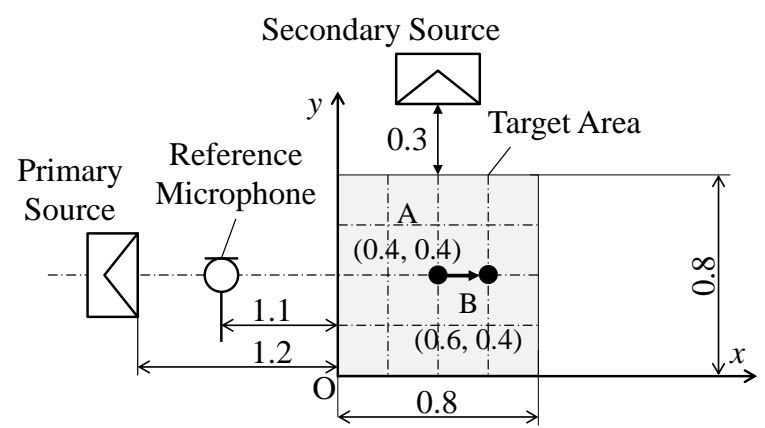

Fig. 6 Orthogonal speaker arrangement in an anechoic chamber.

Table 1 Conditions of measuring acoustic characteristics

\begin{tabular}{|l|l|}
\hline Temperature & $300 \mathrm{~K}$ \\
\hline Identification algorithm & Normalized LMS \\
\hline Measuring time & $10 \mathrm{sec}$ \\
\hline Sampling frequency & $10 \mathrm{kHz}$ \\
\hline Filter length & 1024 \\
\hline Input signal & White noise \\
\hline
\end{tabular}

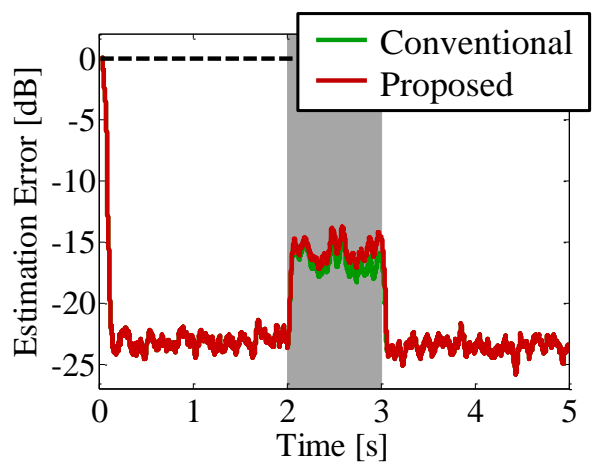

Fig. 8 Result of simulation 1 (Orthogonal).

There is almost no difference of control effect between conventional and proposed method.

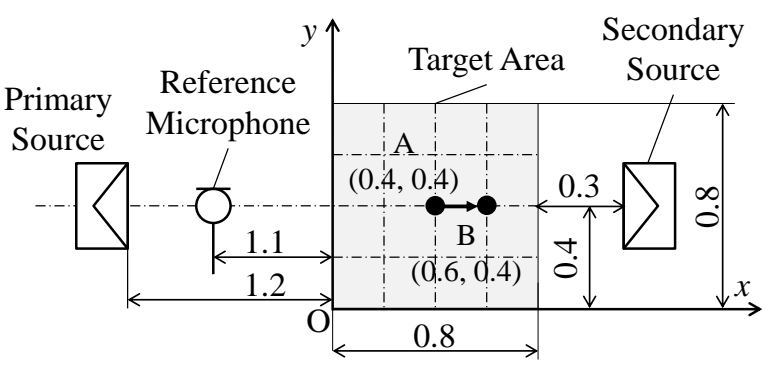

Fig. 7 Opposite speaker arrangement in an anechoic chamber.

Table 2 Conditions of simulation 1

\begin{tabular}{|l|l|}
\hline Sampling frequency & $10 \mathrm{kHz}$ \\
\hline Filter length $L$ & 128 \\
\hline Window length $L_{s}$ & 256 \\
\hline Main function length $L_{w}$ & 128 \\
\hline Ridge parameter $\varepsilon$ & 0.01 \\
\hline Update interval $T_{u}$ & 32 \\
\hline Input signal(noise) & White noise \\
\hline Speed of movement & $0.2 \mathrm{~m} / \mathrm{s}$ \\
\hline
\end{tabular}

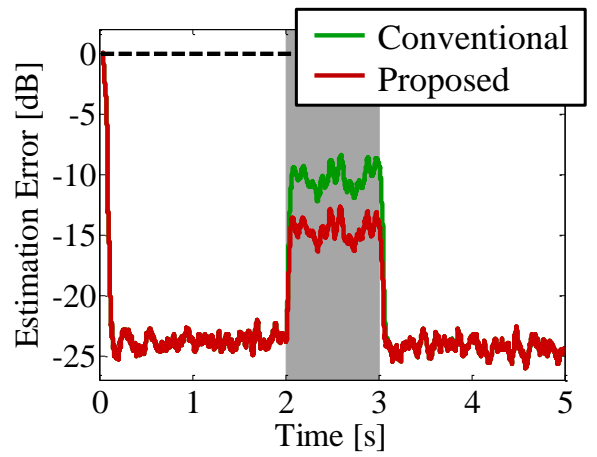

Fig. 9 Result of simulation 1 (Opposite).

Proposed method has better control effect. 
で表される．ここで $e$ は誤差信号， $d$ は所望信号であり，平滑化のためにそれぞれ 512 点平均を取っている．EE は，0で制御効果が無く，值が小さいほど制御効果が高いことを示す．図中には制御効果の有無を示す $E E=0[\mathrm{~dB}]$ に破線を示し, 背景が灰色の部分は評価点が移動している時間帯を示す. 図より, 移動していない時は $\hat{\boldsymbol{G}}$ が変化 しないため, 仮想フィルタードリファレンス信号と従来のフィルタードリファレンス信号が同值となり, 制御効 果に差が現れないことがわかる. また, 直角配置では対向配置の時と比べて移動に伴う 2 次経路特性の変化が少 ない（制御音源から評価点までの距離の変化が少ない）ため, 仮想フィルタードリファレンス信号とフィルター ドリファレンス信号の間の差が小さく, 制御効果にほとんど違いが現れていないことがわかる. しかし対向配置

（図 9）の場合, 仮想フィルタードリファレンス信号を利用寸ると移動時の制御効果が 5[dB]ほど上昇しているこ とがわかる. 以上のことから, 提案法は移動に伴う 2 次経路特性の変化が大きい場合でも, 従来法と比較して安 定した制御効果を示すことがわかる。

\section{$3 \cdot 2$ シミュレーション 2： $\varepsilon$ の変更による制御効果の変化}

2 次経路特性のモデル化誤差による発散を抑制するために導入した $\varepsilon$ の効果について確認する. $3 \cdot 1$ 節と異な り, 制御に用いる 2 次経路特性モデルは大野らによって提案された補間法によって算出し，より実用に近い条件 でシミュレーションを行う. 機器配置は図 7 の対向配置とし, 補間法における 2 次経路特性の事前測定点は, 図 7 に示寸 $0.8 \times 0.8[\mathrm{~m}]$ の制御領域の四隅の 4 点とする. 評価点は図 7 の $\mathrm{A}$ 点から B 点へ $0.2[\mathrm{~m} / \mathrm{s}]$ で移動するもの とする. シミュレーション条件を表 3 に示す. $\varepsilon$ を変化させてシミュレーションを行い，制御効果に与える 影響を調べる.

シミュレーション結果を図 10 に示寸. 図中の横軸は $\varepsilon$ を表し, 縦軸は二乗平均平方根（RMS）を用いて算出し た移動中の $E E$ の平均值を表す. なお縦軸については $E E$ と対応させるため符号を逆転した RMS を示しており, 值が小さいほど制御効果が高いことを示す. 最も高い制御効果を示した $\varepsilon=0.5 \sim 3$ の範囲では $\varepsilon$ を 0.5 ずつ変化 させシミュレーションを行い, $\varepsilon=3 \sim 10$ の範囲では $\varepsilon$ を 1 ずつ, $\varepsilon=10 \sim 100$ の範囲では $\varepsilon$ を 10 ずつ変化さ せてシミュレーションを行ったものを示している. 図 10 より,$\varepsilon=2$ の時に最も高い制御効果を示すことが わかる.

$\varepsilon<2$ の場合, 制御効果が劣化し， $\varepsilon<0.5$ では制御系が発散し制御不能となった. これは実際の 2 次経路特 性と補間された 2 次経路特性の間の誤差（図 3) に対して， $\varepsilon$ の值が不十分であることが原因である. すなわ ち, 補間誤差に起因する適応フィル夕係数の不適切な増大に対して $\varepsilon$ の值が不十分であるため, 式（17）で フィルタ係数の増大が抑制できず, 制御効果の劣化や発散という結果を示したものである.

$\varepsilon>2$ の場合, $\varepsilon$ の増加に伴い制御効果も劣化している.これは式（17）から明らかなように， $\varepsilon$ は適応フ イルタの絶対值を小さくする方向に作用するため, 過度に大きい $\varepsilon$ をえると適切な出力が得られないこと

Table 3 Conditions of simulation 2

\begin{tabular}{|l|l|}
\hline Sampling frequency & $10 \mathrm{kHz}$ \\
\hline Filter length $L$ & 128 \\
\hline Window length $L_{s}$ & 256 \\
\hline Main function length $L_{w}$ & 64 \\
\hline Ridge parameter $\varepsilon$ & $0.5 \sim 100$ \\
\hline Update interval $T_{u}$ & 64 \\
\hline Input signal(noise) & White noise \\
\hline Speed of movement & $0.2 \mathrm{~m} / \mathrm{s}$ \\
\hline
\end{tabular}

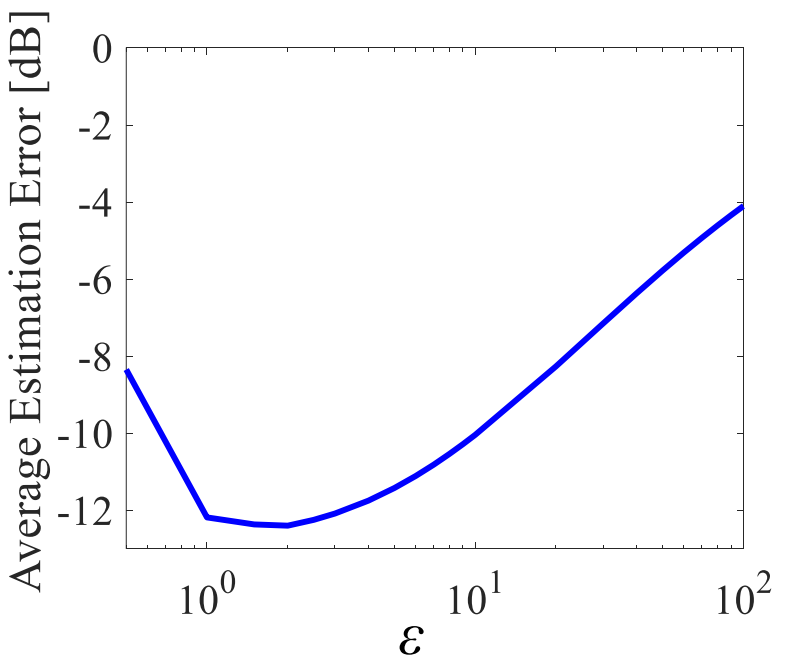

Fig. 10 Result of simulation 2.

Value of $\varepsilon$ changes control effect. 
による。

以上の結果より, 適切な $\varepsilon$ をえることによって 2 次経路のモデル化誤差の影響を軽減し, 制御系を安定化で きることが示された. 式（17）及び図 10 の考察より, $\varepsilon$ の最適值は 2 次経路のモデル化誤差の程度に依存する. よって，2 次経路のモデル化誤差が少ないほど小さな $\varepsilon$ で制御が可能となり，制御効果が向上する.

\section{3 シミュレーション $3:$ 従来のアルゴリズムとの比較 (2 次経路特性のモデル化誤差の影響が大きい場合)}

提案法の有效性を確認するために，他のアルゴリズムとの比較を行う．実用に近い条件でシミュレーションを 行うため, 2 次経路特性モデルは大野らによって提案された補間法によって求められるものとする.よって, 図 3 に示すように, 実際の 2 次経路特性と 2 次経路特性モデルの間には一定の誤差が存在する．機器配置は図 6 の直 角配置, 図 7 の対向配置の 2 種類とする. シミュレーション条件を表 4 に示す. 評価点は図 6 , 図 7 の A 点から B 点へ移動するものとし, 移動速度は $0.2[\mathrm{~m} / \mathrm{s}]$ とする. 比較対象となる従来法は大野らによって提案された LMS アルゴリズムの改良である IP-NLMS-SV（大野他，2013）とする．提案法は，フィルタ長の削減を行う場合と行 わない場合の 2 通りについてシミュレーションを行う.

シミュレーション結果を図 11（直角配置）及び図 12 (対向配置) に示す，従来法である IP-NLMS-SV を緑， フィルタ長の削減を行わない場合 $\left(L_{w}=L=128\right)$ の提案法を青, フィルタ長の削減を行った場合の提案法 $\left(L_{w}\right.$ $=L / 2=64 ）$ を赤で示している. 図 11 及び図 12 より, 対向配置の場合, 従来法と比べて提案法は移動中の制御効果 が改善していることがわかる. 図 13, 図 14 は直角配置, 対向配置それぞれの A 点及び B 点での適応フィルタ $\boldsymbol{C}$ の最適值（最適フィルタ）を示したものである. 直角配置と比べて, 対向配置では最適フィルタの変化が比較的 大きい. このように最適フィルタの変化が大きい場合, 従来法では制御効果が大きく劣化してしまうが，提案法 では劣化の程度が抑えられ，従来法より高い制御効果を維持できることがわかる. 3.1 節及び本節の結果から, 移動に即した仮想フィルタードリファレンス信号を導入した提案法は, 2 次経路特性及び最適フィルタが大きく 変化する場合でも安定した制御効果を持つ, 評価点の移動に適した ANC システムであることがわかる.

評価点停止時は，従来法と比較して提案法の制御効果は悪い. $3 \cdot 2$ 節で述べたように，2 次経路特性のモデル

Table 4 Conditions of simulation 3

\begin{tabular}{|l|l|}
\hline Sampling frequency & $10 \mathrm{kHz}$ \\
\hline Filter length $L$ & 128 \\
\hline Window length $L_{s}$ & $128\left(L_{w}=64\right), 200\left(L_{w}=128\right)$ \\
\hline Main function length $L_{w}$ & 64,128 \\
\hline Ridge parameter $\varepsilon$ & 2 \\
\hline Update interval $T_{u}$ & $64\left(L_{w}=64\right), 100\left(L_{w}=128\right)$ \\
\hline Input signal(noise) & White noise \\
\hline Speed of movement & $0.2 \mathrm{~m} / \mathrm{s}$ \\
\hline
\end{tabular}

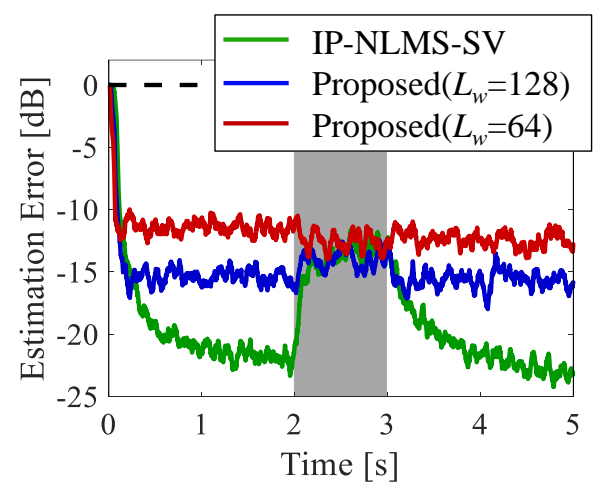

Fig. 11 Result of simulation 3 (Orthogonal).

There is almost no difference of control effect during movement.

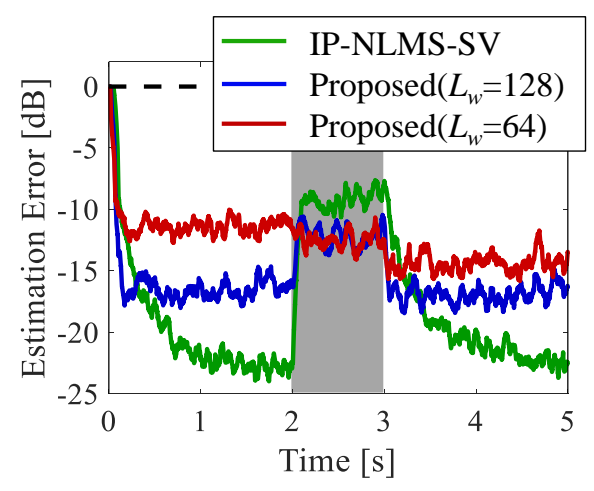

Fig. 12 Result of simulation 3 (Opposite).

Proposed method has better control effect. 
化誤差が存在すると $\varepsilon$ の值を大きく取らなければならないため, モデル化誤差の増加に伴い制御効果は劣化する. 今回のシミュレーションでは図 6 及び図 7 に示寸 $0.8 \times 0.8[\mathrm{~m}]$ の制御領域の四隅の 4 点から 2 次経路特性を補間し ており，十分な補間精度が得られなかったため, 評価点停止時には従来法に匹敵する制御効果を得ることができ なかったと考えられる．2 次経路特性のモデル化誤差が少ない場合のシミュレーションについては 3.4 節で述べ る.

また, シミュレーションに要した時間を表 5 に示す. シミュレーションは市販パーソナルコンピュータ上で MATLAB により行った．提案法のシミュレーション時間は，計算量の削減を行う場合（ $L_{w}=64 ）$ では，従来法と 比べて 2 割程度の増加に留まっており，現実的な時間でアルゴリズムを実行できることが確認された.

\section{4 シミュレーション 4：従来のアルゴリズムとの比較 (2 次経路特性のモデル化誤差の影響が小さい場合)}

3.3 節において評価点停止時に従来法と比較して制御効果が劣化した理由は，2次経路特性の補間誤差に起因 すると考えられる，そこで本節では，2 次経路特性のモデル化誤差が少ない場合のシミュレーションを行い，従 来法と制御効果を比較する. 2 次経路特性モデルはシミュレーション用に測定した 2 次経路特性フィルタ（フィ ルタ長 1024）を128 で打ち切ったものを使用する. 2 次経路特性モデルにはフィルタ長の打ち切り誤差が存 在するが，それ以外の誤差が存在しないため, 3.3 節で用いた補間法より精度の高い 2 次経路特性モデルを使 用することになる．このシミュレーションでは， $\varepsilon$ を変化させ最適值を調べ， $\varepsilon=0.01$ とした．機器配置は図 6 の直角配置, 図 7 の対向配置の 2 種類とし, 評価点は A 点から B 点へ $0.2[\mathrm{~m} / \mathrm{s}]$ で移動するものする. シミュレ ーション条件を表 6 に示す.

シミュレーション結果を図 15 (直角配置) 及び図 16 (対向配置) に示寸. 3.3 節と同じく, 対向配置で評価点 移動時の制御効果が大きく向上していることがわかる．評価点移動時における従来法との制御効果の差は， $3 \cdot 3$ 節では 3 5 [dB]の向上であったのに対して, 今回のシミュレーションでは 5 9 [dB]の向上となっている. また, 3.3 節では, 評価点停止時において提案法の制御効果が劣化していたが, 今回のシミュレーションでは評価点停 止時でも同程度の制御効果が得られていることがわかる. 収束速度に着目寸ると, 従来法が収束までに 1 秒程度

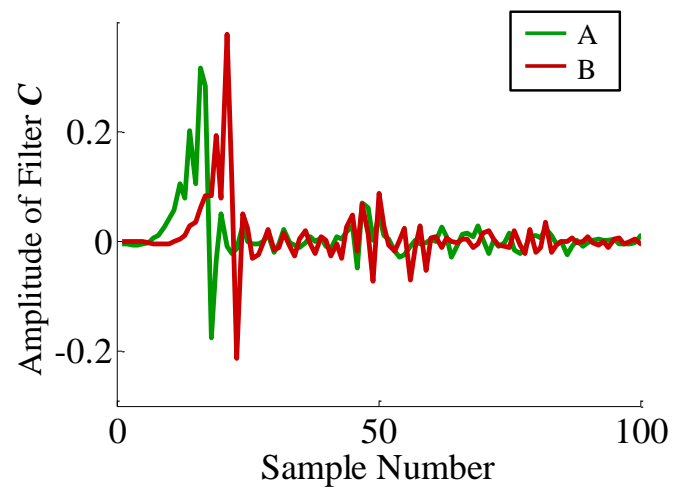

Fig.13 Variation of adaptive filter of Orthogonal direction arrangement is comparatively few.

Table 5 Simulation time of conventional and proposed method

\begin{tabular}{|l|l|l|}
\hline & Opposite & Orthogonal \\
\hline IP-NLMS-SV & $37.9[\mathrm{~s}]$ & $39.3[\mathrm{~s}]$ \\
\hline $\begin{array}{l}\text { Proposed } \\
\left(L_{w}=128\right)\end{array}$ & $69.2[\mathrm{~s}]$ & $68.3[\mathrm{~s}]$ \\
\hline $\begin{array}{l}\text { Proposed } \\
\left(L_{w}=64\right)\end{array}$ & $44.9[\mathrm{~s}]$ & $46.2[\mathrm{~s}]$ \\
\hline
\end{tabular}

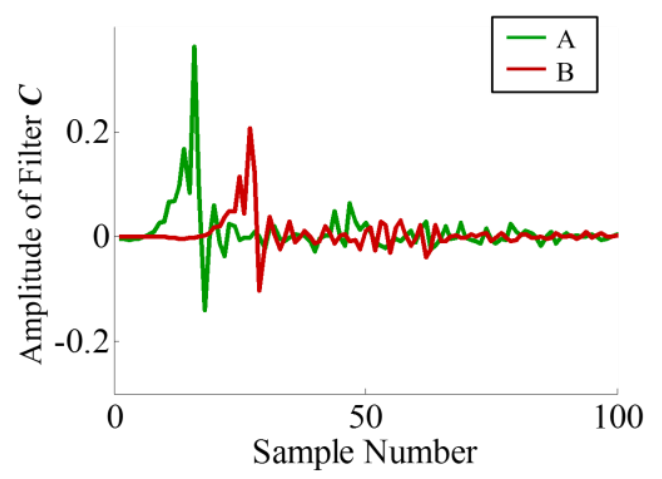

Fig.14 Variation of adaptive filter of Opposite direction arrangement is large.

Table 6 Conditions of simulation 4

\begin{tabular}{|l|l|}
\hline Sampling frequency & $10 \mathrm{kHz}$ \\
\hline Filter length $L$ & 128 \\
\hline Window length $L_{s}$ & 256 \\
\hline Main function length $L_{w}$ & 128 \\
\hline Ridge parameter $\varepsilon$ & 0.01 \\
\hline Update interval $T_{u}$ & 8 \\
\hline Input signal(noise) & White noise \\
\hline Speed of movement & $0.2 \mathrm{~m} / \mathrm{s}$ \\
\hline
\end{tabular}


の時間を要しているのに対し, 提案法では 0.1 秒程度で収束していることがわかる. 以上より, 提案法は 2 次経 路特性のモデル化誤差が少ない場合において, 評価点停止時・移動時にかかわらず従来法より高い制御効果を持つ ことがわかる。

\section{4. 制 御 実 験}

本章では無響室内における実験によって提案法の有効性を確認する. 機器配置は図 6 の直角配置及び図 7 の対 向配置の 2 通りとする．接続図を図 17 に，実験条件を表 7 に示す，実験装置は図 18 の一軸マイク移動装置を用 いる．誤差マイクはプーリーでモーターと接続されており，リニアガイドに沿って移動する．位置情報はエンコ ーダーから制御系に送られる。

評価点は図 6, 図 7 の A 点から $\mathrm{B}$ 点へ移動するものとし，移動速度は $0.2[\mathrm{~m} / \mathrm{s}]$ とする. 3.3 節と同様に，比較 対象となる従来法は大野らによって提案された IP-NLMS-SV とする.

今回の実験では制御に用いる DSP（エムティティ社製 s-BOX）の計算能力上の制約から，更新対象フィルタ長 $L_{w}$ を 30 とし， 2 次経路特性モデル $\hat{\boldsymbol{G}}$ は補間による計算量を省くため, 移動経路上で $1[\mathrm{~cm}]$ 刻夕で測定した 21 点 の 2 次経路特性をそのまま用いることとする. $3 \cdot 2$ 節で述べたように, $\varepsilon$ の最適值は 2 次経路特性のモデル化誤 差に依存する. 3.2 節や 3.3 節のシミュレーションでは, $0.8 \times 0.8[\mathrm{~m}]$ の制御領域の四隅の 4 点における 2 次経路 特性を事前測定し，大野らによって提案された補間法を用いて制御を行っていた。 それに対し，今回の実験では

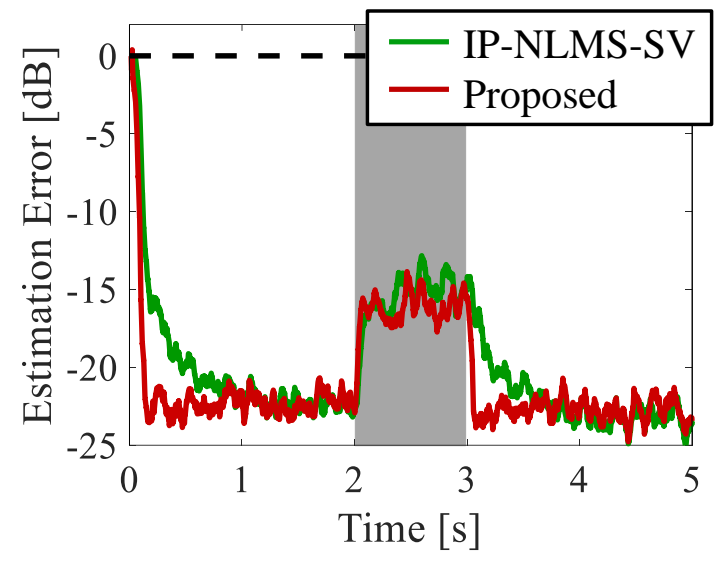

Fig. 15 Result of simulation 4 (Orthogonal).

By the proposed method, the control effect when an evaluation point stops is improved.

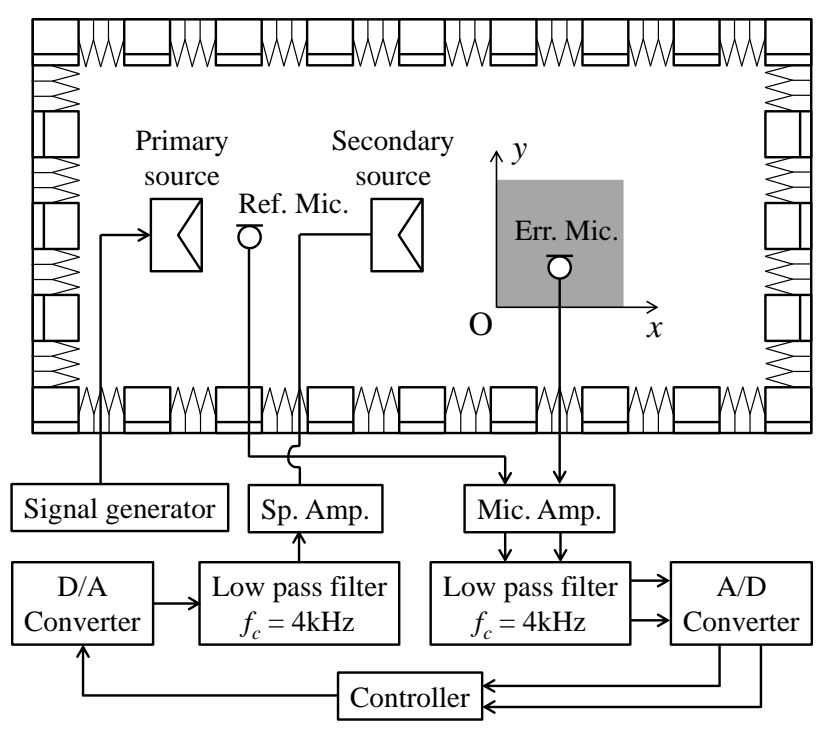

Fig.17 Signal flow of ANC experiment.

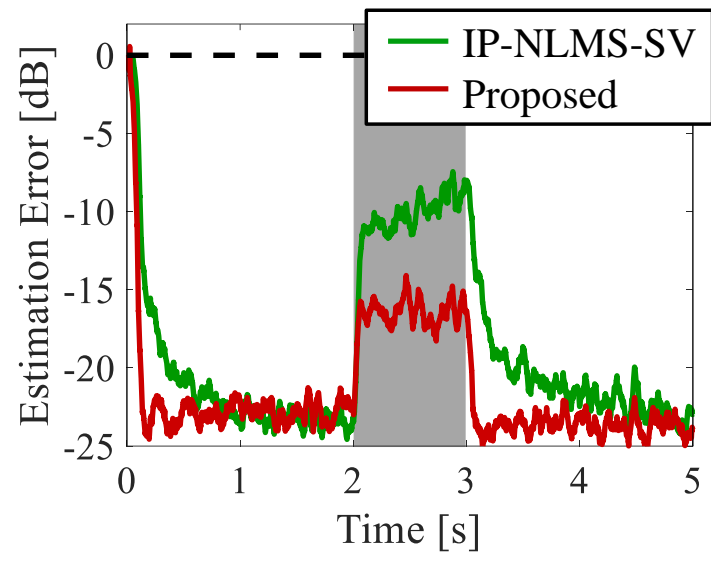

Fig. 16 Result of simulation 4 (Opposite). In all simulation time, the control effect is improved by the proposed method.

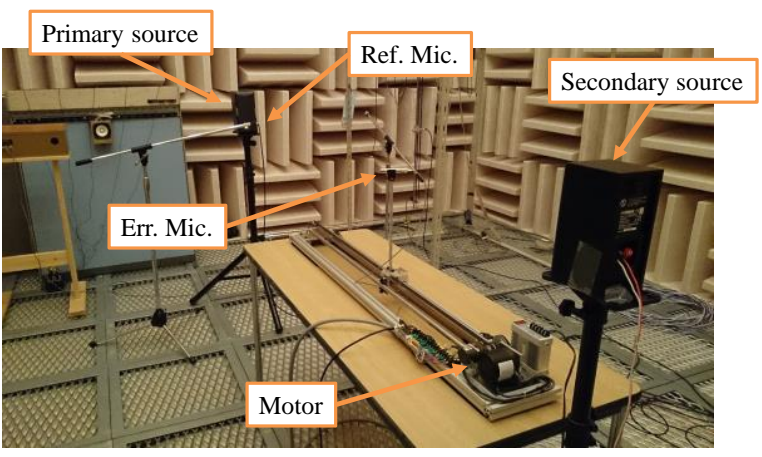

Fig. 18 Experimental equipment. 
$1[\mathrm{~cm}]$ 刻みで 2 次経路特性を測定しており, より精度の高い 2 次経路特性モデルが得られるため, 3.2 節や 3.3 節と異なり $\varepsilon=1$ とした。

実験結果を図 19 及び図 20 に示す．図 19 は直角配置, 図 20 は対向配置の結果を示す．まず直角配置, 対向配 置ともに評価点停止時の制御効果は従来法と比較して提案法の方が悪いことがわかる. これは従来法のフィルタ 長が 128 であるのに対し，上述したようにDSP の計算能力上の制約から提案法の実質的なフィルタ長 $L_{w}$ を 30 と せざるを得ず，評価点停止時の IP-NLMS-SV に匹敵するフィルタ精度を出すことができなかったことが大きな原 因である. また， 2 次経路特性のモデル化誤差に起因するペナルティ係数 $\varepsilon=1$ の導入も，評価点停止時の制御 効果劣化の一因となっていると考えられる.

評価点移動時に着目寸ると, 図 19 の直角配置では従来法と提案法の評価点移動時の制御効果はほぼ同等である. これは 3.1 節のシミュレーション結果と一致しており, 図 13 に示したように直角配置では最適フィルタの変化 が小さいため IP-NLMS-SV でも高精度のフィルタを算出できたこと，及び 2 次経路特性がほとんど変化しないた め提案法における仮想フィルタードリファレンス信号導入の効果がほとんどなかったことによる．しかし図 20 の対向配置では, 評価点移動時において提案法が高い制御効果を持つ. これは図 14 で示したように最適フィルタ が大きく変化し, IP-NLMS-SVでは制御効果を大きく悪化させているのに対して, 提案法では仮想フィルタード リファレンス信号の導入により，2 次経路特性及び最適フィルタの変化にかかわらず安定して高い制御効果を維 持できたためである.

以上の実験より，提案法は最適フィルタや 2 次経路特性が大きく変化する場合，すなわち評価点が移動する場 合の ANCにおいて特に有効であることが示された. また,一般的な DSP でアルゴリズムが実行可能であること， 及び 2 次経路特性のモデル化誤差にかかわらずアルゴリズムが実行できたことから, 第 3 章で述べた計算量削減 法及び 2 次経路特性へのモデル化誤差への対応の有効性が示された.

Table 7 Conditions of ANC experiment

\begin{tabular}{|l|l|}
\hline Sampling frequency & $10 \mathrm{kHz}$ \\
\hline Filter length $L$ & 128 \\
\hline Window length $L_{s}$ & 128 \\
\hline Main function length $L_{w}$ & 30 \\
\hline Ridge parameter $\varepsilon$ & 1 \\
\hline Update interval $T_{u}$ & 64 \\
\hline Input signal(noise) & White noise \\
\hline Speed of movement & $0.2 \mathrm{~m} / \mathrm{s}$ \\
\hline
\end{tabular}

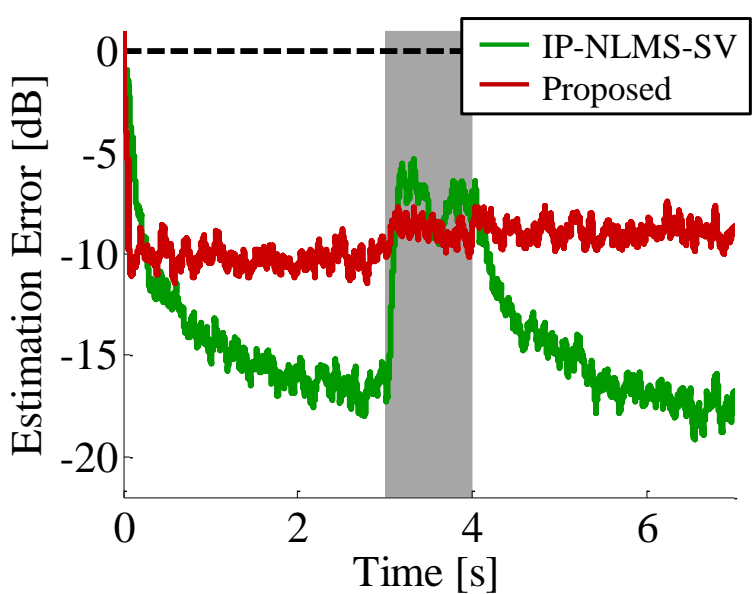

Fig.19 Result of experiment(Orthogonal).

The difference between conventional and proposed method is small.

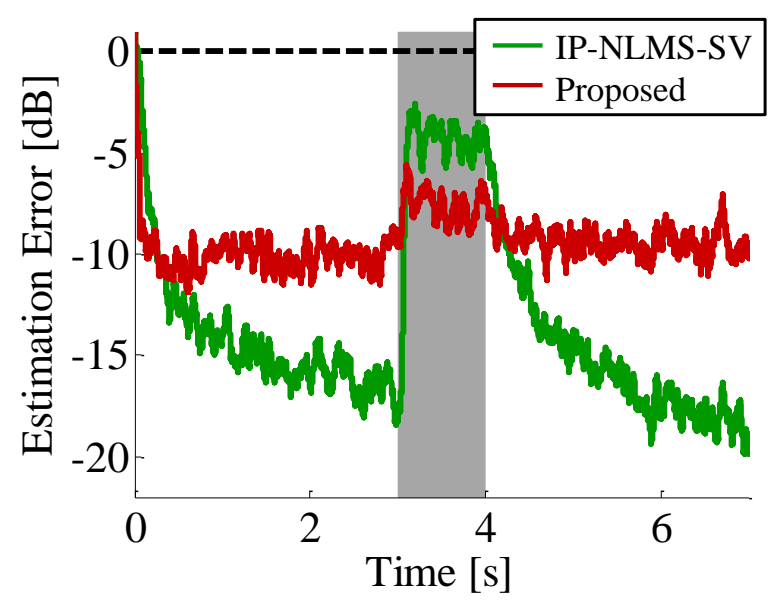

Fig. 20 Result of experiment(Opposite).

Proposed method has better control effect. 


\section{5. おわりに}

本論文では，3 次元空間内の能動音響制御において，評価点が移動する場合の制御効果を向上する手法を検討 した.

RLSアルゴリズムに用いられる仮想的な誤差信号を移動に即した形に修正することで評価点移動時の制御効果 向上を図る参照信号修正法（Modified Reference signal Method, MRM）を提案した． 2 次経路特性のモデル化誤差 による発散を抑制するために評価量にペナルティ項を導入した．また，計算量を削減するために主要部のみを更 新対象とし, フィルタ更新頻度を低下させる方法を提案した。

また，提案法の有効性を確認するために数值シミュレーションを行った．仮想フィルタードリファレンス信号 の導入により, 評価点の移動に伴い最適フィルタ及び 2 次経路特性が大きく変化する場合において, 従来のフィ ルタリング方法と比較して提案法は高い制御効果を持つことを確認した．また，ペナルティ項の導入により 2 次 経路のモデル化誤差が存在する場合でも安定して制御を行えることを確認し，2 次経路のモデル化誤差が少ない ほど高い制御効果を持つことを示した. 従来法と提案法の比較では, 大野らの補間法を用いて制御を行った場合, 評価点停止時は 2 次経路のモデル化誤差の影響により従来法より制御効果が劣化しているものの, 評価点移動時 は高い制御効果を持つことを確認した. 2 次経路特性のモデル化誤差がより少ない条件でのシミュレーションで は，評価点移動時·停止時に関わらず提案法は従来法と比較して高い制御効果を持つことを確認した.

最後に実験で提案法の有効性を確認した. DSP の計算能力上の制約及び 2 次経路のモデル化誤差の影響から評 価点停止時の制御効果が劣化したものの, シミュレーションと同様に, 提案法は最適フィルタ及び 2 次経路特性 が大きく変化する場合，すなわち評価点が移動する場合でも従来法と比較して高い制御効果を持つことを確認し た. また，一般的な DSPでリアルタイムに制御が行えること，及び 2 次経路特性のモデル化誤差が存在する場合 でも安定して制御可能であることを確認した.

以上より，提案法は評価点移動に追従する ANC システムとして高い制御効果を持ち，実用的なアルゴリズム であることが示された。

\section{文献}

Haykin, S., (鈴木博, 府川和彦, 大鐘武雄, 高田潤一, 村田英一, 真田幸俊 訳), 適応フィルタ理論(2001), pp.630-658.

西村 正治，伊勢 史郎，宇佐川 毅，アクティブノイズコントロール(2006), p.75.

落合悟志, 堀田英輔, 2 次経路の推定誤差を考慮した Leaky Filtered-X RLSアルゴリズム, 電子情報通信学会技術研 究報告, Vol.107, No.441 (2008), pp.39-44.

大野佳子, 木庭洋介, 石川諭, 雉本信哉, ステップサイズベクトルと 2 次経路特性補間法を用いた評価点移動時の 能動音響制御，日本機械学会論文集 B 編, Vol.79, No.801 (2013), pp.734-738.

鈴木昭次, 西村正治, 雉本信哉, 御法川学, 機械音響工学(2004), pp.160-164.

\section{References}

Haykin, S., (interpreted by Suzuki, H., Fukawa, T., Ohgane, T., Takada, J., Murata, H. and Sanada, Y.), Adaptive Filter Theory(2001), pp.630-658, Kagaku Gijutsu Shuppan, Inc. (in Japanese).

Nishimura, M., Ise, S. and Usagawa, T., Active Noise Control(2006), p.75 (in Japanese).

Ochiai, S. and Horita, E., A leaky filtered-x RLS algorithm using an estimation error in the secondary path, The technical report of the proceeding of The Institute of Electronics, Information and communication Engineers, Vol.107, No.441(2008), pp.39-44 (in Japanese).

Ohno, Y., Koba, Y., Ishikawa, S. and Kijimoto, S., Active Noise Control for a Moving Evaluation Point Using Stepsize Vector and Interpolation of Secondary Path, Transactions of the Japan Society of Mechanical Engineers, Series C, Vol.79, No.801(2013), pp.734-738 (in Japanese).

Suzuki, S., Nishimura, M., Kijimoto, S. and Minorigawa, G., Mechanical Acoustical Engineering(2004), pp.160-164, Corona Publishing co ltd. (in Japanese). 